\title{
The Role of Prosecution Related to Prosecutor's Demand in Enforcing the Criminal Action of Narcotics
}

\author{
Septian Nanang Pangestu ${ }^{*}$ and Lathifah Hanim*) \\ *) Student of Master of Law, Faculty of Law, Universitas Islam Sultan Agung Semarang, \\ E-mail: septiannanang76@gmail.com \\ **) Faculty of Law, Universitas Islam Sultan Agung Semarang
}

\begin{abstract}
The objectives of this research are: to analyze prosecutors related to prosecutors 'demands in enforcing the narcotics crime law. To analyze the obstacles and solutions faced in making prosecutors' demands in enforcing the narcotics crime law.The method used by researchers isjuridical sociological approach to law and the specification in this research is including analytical descriptive. Based on the results of the research that the role of the prosecutor related to prosecutors' demands in enforcing the narcotics crime law has been fulfilled. The elements of a criminal act violating Article 127 paragraph (1) letter a of Act No. 35 of 2009 concerning Narcotics and it was proven to be against the law because the defendant had the intention to use methamphetamine himself or his own interests, while drugs can only be used for the benefit of developing science and technology. The obstacle is that witnesses who are majority members of the police, when called to be witnesses at trial, often do not attend the trial because they are busy with their superiors, which makes the prosecution process take a long time. The modus operandi in narcotics convictions is because the perpetrators work very well. To overcome the obstacles prosecutors carry out an activity, one of which is holding knowledge sharing meetings between law enforcers and related agencies, to gain unity in perceptions in handling Narcotics crime cases. Then carry out management improvements, so as to minimize the opportunity for narcotics crime to occur. Starting from the practice of handling narcotics crime, the first origin of narcotics crime is from one of the weaknesses of management.

Keywords: Role; Attorney General's Office; Prosecution; Law Enforcement; Legal Certainty; Crime; Narcotics.
\end{abstract}

\section{Introduction}

Ratification of the 1971 Vienna Convention which regulates international cooperation in controlling, controlling the production, distribution and use of narcotics and psychotropic substances as well as preventing efforts to eradicate the abuse of narcotics and psychotropics, by limiting their use only for medicinal and scientific purposes This is an attempt by the government to organize cooperation between other countries in the framework of an effort to control, distribute and abuse of psychotropic substances and narcotics which provide direction on criminal juridical principles and rules on extradition. ${ }^{1}$

Drug abuse is still a chronic problem that afflicts Indonesia, cases of methamphetamine distribution and the many arrests of international drug dealers in recent years are proof that Indonesia is in a state of drug emergency. The Indonesian

\footnotetext{
${ }^{1}$ Sepha Dwi Hananto, Anis Mashdurohatun, Jawade Hafidz, Penegakan Hukum Pidana Terhadap Terdakwa Pengguna Narkoba Yang Menjalani Rehabilitasi Di Polda Jateng, Jurnal Hukum Khaira Ummah Vol. 13. No. 1 March 2018
} 
government puts forward the role of the Police and the National Narcotics Agency (BNN) in order to prevent and eradicate drug trafficking in Indonesia. ${ }^{2}$

The abuse and illicit trafficking of narcotics is nothing new in Indonesia. Narcotics crime is a form of violation of law and violation of social norms that have existed for a long time and it is very difficult for a country to eradicate it. Almost every day the mass media in Indonesia and outside Indonesia report about the abuse of Narcotics. Narcotics are substances that can have a certain effect on the user by inserting the drug into their body, this effect is refraction, loss of pain, enthusiasm and hallucinations. ${ }^{3}$ Narcotics is an addictive substance because it causes dependence and is classified as a psychoactive substance, meaning that it affects the work of the brain and changes the behavior of the user. ${ }^{4}$ Groups included in narcotics are opium, morphine, marijuana, heroin, cocaine, ecstasy, methamphetamine, and sedative drugs. The abuse of narcotics qualifies as a criminal act in Act No. 35 of 2009 concerning Narcotics. The application of the criminal system against the perpetrators of the crime of child abusers is a humanistic approach that takes into account the principle of criminal individualization in the use of criminal sanctions as a means of tackling crime. In essence, narcotics abusers are also victims who need medical assistance. The implementation of measures in the form of medical and social rehabilitation aims to improve the condition of narcotics abusers so that they are free from narcotics dependence so that they can return to society naturally. ${ }^{5}$

The success of law enforcement efforts for narcotics abuse is strongly influenced by dependence and involvement between elements of the police, prosecutors, courts and prisons, so all law enforcement officials in carrying out their duties must comply with the applicable legal channels. For this reason, based on the law governing the use of narcotics, namely Act No. 35 of 2009 concerning Narcotics in Article 4 and Article 7 as follows: Article 4 the regulation of narcotics aims to:

- Guarantee the availability of narcotics for the benefit of health services and or the development of science and technology.

- Prevent, protect and save the Indonesian people from the abuse of Narcotics abuse.

- Eradicating the illicit trafficking of Narcotics and Narcotics Precursors, and

- Ensure the arrangement of medical and social rehabilitation efforts for drug abusers and addicts.

The objectives of this research are: to analyze the prosecution regarding the prosecutors' demands in enforcing the narcotics crime law. To analyze the obstacles and solutions faced in carrying out prosecutors' demands in enforcing the narcotics crime law.

\footnotetext{
${ }^{2}$ Bayu Puji Hariyanto, Pencegahan Dan Pemberantasan Peredaran Narkoba Di Indonesia, Jurnal Daulat Hukum Vol. 1. No. 1 March 2018 ISSN: 2614-560X, Unissula

3 Juliana Lisa, Nengah Sutrisna. (2003). Narkoba Psikotropika dan Gangguan Jiwa. Yogyakarta: Nuha Medika. p. 1

${ }^{4}$ Ibid, p. 3

${ }^{5}$ Dafit Supriyanto Daris Warsito, Sistem Pemidanaan Terhadap Pelaku Tindak Pidana Penyalahguna Narkotika, Jurnal Daulat Hukum Vol. 1. No. 1 March 2018 ISSN: 2614-560X, Unissula
} 


\section{Research methods}

In this study, using the most appropriate approach, namely the Sociological Juridical approach. As a form of method, the approach used is to find out the realities in the field based on the principles of law or legislation in force and have something to do with the object being studied. ${ }^{6}$ The sources and types of data in this study are secondary data. The data collection method is obtained from literature study. The data were analyzed qualitatively.

\section{Result and Discussion}

\subsection{The Role of the Prosecutor regarding the Prosecutor's Claims in Law Enforcement of Narcotics Crime}

The Attorney General's Office plays an important role in prosecuting the court in the Narcotics case to prove the defendant's guilt in court. If there is an error in determining the insufficient evidence, this may result in the release of the defendant from all charges. If it does not fulfill the elements mentioned in Article 183 KUHAP, the decision making of the judge in the trial will result in obscurity so that it can have an impact on the sentence of the accused. This situation can result if the prosecution is not carried out by fulfilling sufficient evidence. ${ }^{7}$

Elements of Article 127 paragraph (1) letter (a) RI Act No. 35 of 2009 concerning Narcotics, so that the Assembly of Article 112 paragraph (1) in conjunction with Article 132 paragraph (1) of Law of the Republic of Indonesia Number 35 of 2009 with the following elements:

- Each person;

- Criminal Attempts or Conspiracy to Commit the Crime of Narcotics and Narcotics Precursors, namely Without Rights or Against the Law in possession, keeping, controlling, or providing narcotics

The defendant's actions had been proven to be against the law because the defendant had the intention to use methamphetamine himself or his own interests, while it was known that drugs could only be used for the purpose of developing science and technology and was prohibited for other purposes. Then based on the legal considerations above, this second element has been proven and fulfilled.

The role of the prosecutor regarding the prosecutor's demands in law enforcement for the criminal act of narcotics has fulfilled the elements of a crime violating Article 127 paragraph (1) letter a of Act No. 35 of 2009 concerning Narcotics and it was proven to be against the law because the defendant had the intention to use methamphetamine himself or his own interests, while drugs can only be used for the benefit of developing science and technology.

\subsection{Constraints and solutions faced in carrying out prosecutors' demands in enforcing the Narcotics Crime Law}

\footnotetext{
${ }^{6}$ Ronny Hanitijo Soemitro. (1998). Metode Penelitian Hukum dan Jurimetri. Jakarta: Ghalia. p.97

${ }^{7}$ Romli Atmasasmita. (1996). Sistem Peradilan Pidana Indonesia. Jakarta: Putra Bardin. p.33
} 
The problem of narcotics abuse is not only a problem that needs attention for the Indonesian state, but also for the international community. Entering the 20th century the international attention to the problem of narcotics is increasing, one can see through the Single Convention on Narcotic Drugs in $1961 .^{8}$ This problem becomes so important considering that drugs (narcotics) are substances that can damage physically and mentally the person concerned, if the user is without a doctor's prescription.

The application of legal sanctions in the form of rehabilitation for addicts and users as perpetrators of drug abuse will reduce the excess capacity of prisons in addition to reducing illicit drug trafficking, for that the judicial framework already in place in Act No. 35 of 2009 should be used by judges in deciding addicts and drug users, namely Article 54 of Act No. 35 of 2009 concerning Narcotics. Article 54 of the Narcotics Law states that narcotics addicts and victims of Narcotics abuse are required to undergo medical rehabilitation and social rehabilitation. ${ }^{9}$

Thus it can be explained that before prosecuting an incident, it will first conduct an examination of the case file and notify investigators of whether the case file is complete or not. However, in practice, the public prosecutor still has several obstacles in enforcing the law on the crime of narcotics, one of the obstacles for the public prosecutor is as follows: Witnesses who are majority members of the police, when called to be witnesses in court, often do not appear in court because they are busy with their superior, thus making the prosecution process longer. In the case that the filing of a narcotics crime is sometimes incomplete from the investigator who has been delegated to the Public Prosecutor, then the file is returned to the investigator, causing the case files to go back and forth from the investigator. The difficulty that arises is in the case of prosecution to find evidence of the increasingly varied modus operandi of narcotics convictions, because the way the perpetrators work is very clever.

Recently narcotics and illegal drug crimes have been transnational in nature carried out with a high modus operandi and sophisticated technology, law enforcement officials are expected to be able to prevent and overcome these crimes in order to improve morality and the quality of human resources in Indonesia, especially for the next generation. ${ }^{10}$ Drug abuse is closely related to illicit traffic as part of the world of international crime. The illicit trafficking mafia supplies drugs so that people become dependent so that the supply increases. The relationship between the dealer/dealer and the victim makes it difficult for the victim to break away from the dealer/dealer, and sometimes even the victim is also involved in illicit trafficking due to their increased need for and dependence on drugs. ${ }^{11}$

Transnational drug crimes are carried out using the modus operandi and sophisticated technology, including securing the proceeds of drug crime. The development of the

\footnotetext{
${ }^{8}$ Kusno Adi. (2009). Kebijakan Kriminal Dalam Penanggulangan Tindak Pidana Narkotika Oleh Anak. Malang: UMM Press. p. 30.

${ }^{9}$ Hera Saputra, Munsyarif Abdul Chalim, Penerapan Sistem Pemidanaan Terhadap Pelaku Tindak Pidana Penyalahgunaan Narkoba (Studi Kasus di Polda Jateng), Jurnal Daulat Hukum Vol. 1. No. 1 Maret 2018 ISSN: 2614-560X, Unissula

${ }^{10}$ Bambang Hariyono. (2009). Kebijakan Formulasi Hukum Pidana Terhadap Pelaku Tindak Pidana Narkoba di Indonesia. Universitas Diponegoro Semarang, p.23

11 Lydia Harlina Martono \& Satya Joewana. (2006). Membantu Pemulihan Pecandu Narkoba dan Keluarganya. Jakarta: Balai Pustaka. p.1.
} 
quality of drug crime has become a very serious threat to human life. Even though drugs are very useful and necessary for treatment and health services, if they are misused or used not in accordance with treatment standards, especially if accompanied by illicit drug trafficking, they will have very detrimental consequences for individuals and society, especially the younger generation, and can even cause more harm great for the life and cultural values of the nation. ${ }^{12}$

The prosecutor's office is an institution, body, and government institution that exercises state power in the field of prosecution and other powers. Meanwhile, the person who performs the duties, functions and authority is called a prosecutor. This is confirmed in Article 1 paragraph (1) of the Prosecution Law, namely, "Prosecutors are functional officials who are authorized by law to act as public prosecutors and implement court decisions that have permanent legal force and other powers based on law". So, it needs to be underlined that in addition to his duties in the field of prosecution, other authorities are also given by law, for example as State Attorney, Executor for court decisions that have permanent legal force, as investigator of certain crimes. $^{13}$

The Attorney General's Office plays an important role in prosecuting the court in the Narcotics case to prove the defendant's guilt in court. If there is an error in determining the insufficient evidence, this may result in the release of the defendant from all charges. If it does not fulfill the elements mentioned in Article 183 KUHAP, the decision making of the judge in the trial will result in obscurity so that it can have an impact on the sentence of the accused. This situation can be caused if the prosecution is not carried out by fulfilling sufficient evidence. ${ }^{14}$

The attorney's efforts to overcome obstacles in upholding and legal certainty of narcotics crime that have been carried out so far are as follows: Holding knowledge sharing meetings between fellow law enforcers and related agencies, to gain unity of perception in handling Narcotics crime cases. Carry out management improvements, so as to minimize the opportunities for narcotics crime. From the practice of handling narcotics crime, the first origin of narcotics crime is from a management weakness. Conducting legal counseling regarding narcotics crime in the community, especially in rural communities, often the dealers influence the general public (village community) who do not know whether these items are marijuana, narcotics, with the dealer mode by giving large sums of money to the courier (delivery service). Coordinating with related agencies such as airports and ports to anticipate the circulation of narcotics sent by expedition. Continuing the education of prosecutors, especially the Narcotics Crime, so that there are special prosecutors in handling narcotics crimes, or by participating in the training of officers involved in handling narcotics crimes to have more control over the rules of narcotics crime. The program of Attorney for School, this activity is to provide education to students regarding the dangers and effects of narcotics use among school children or by participating in the training of officers involved in the handling of narcotics crime to have more control over the narcotics crime regulations. The program of Attorney for School, this activity is to provide

\footnotetext{
${ }^{12}$ Muhammad Taufik Makarao. (2003). Tindak Pidana Narkotika. Jakarta: Ghalia Indonesia. p.26

${ }^{13}$ Article 1 paragraph (1) of Act No. 16 of 2004 concerning Public Prosecutors Office

${ }^{14}$ Romli Atmasasmita, Op. Cit, p.33
} 
education to students regarding the dangers and effects of narcotics use among school children.

\section{Closing}

The role of the prosecutor regarding the prosecutor's demands in law enforcement for the criminal act of narcotics has fulfilled the elements of a crime violating Article 127 paragraph (1) letter a of Act No. 35 of 2009 concerning Narcotics and it was proven to be against the law because the defendant had the intention to use methamphetamine himself or his own interests, while drugs can only be used for the benefit of developing science and technology. Constraints in law enforcement on narcotics crime, witnesses who are majority members of the police, when called to be witnesses in court, often do not appear in court due to busyness with their superiors, thus making the prosecution process take a long time, Then the difficulty that arises is in the case of investigators finding evidence of the increasingly varied modus operandi of narcotics convictions, because the perpetrators work very well. To overcome the obstacles prosecutors carry out an activity, one of which is holding knowledge-sharing meetings between law enforcement and related agencies, to get a unity of perception in handling Narcotics crime cases. Then carry out management improvements, so as to minimize the opportunity for narcotics crime to occur. Starting from the practice of handling narcotics crime, the first origin of narcotics crime is from one of the weaknesses of management.

It is hoped that the Attorney General's Office in carrying out its role must have the courage to exercise discretion in accordance with applicable regulations, break through rules by prioritizing reason, upholding human rights, public interests, and justice in prosecuting Narcotics cases because the Narcotics issue concerns the public interest. It is hoped that the Narcotics Law authorizes the Attorney to also act as investigators as this is regulated in a special law. By enabling the prosecutor to act as an investigator, the public prosecutor can obtain the actual facts in the field, making it easier for the public prosecutor to defend his evidence at trial and can also distinguish the facts in alternative charges.

\section{References}

\section{Journals:}

[1] Bayu Puji Hariyanto, Pencegahan Dan Pemberantasan Peredaran Narkoba Di Indonesia, Jurnal Daulat Hukum Vol. 1. No. 1 March 2018 ISSN: 2614-560X, Unissula

[2] Dafit Supriyanto Daris Warsito, Sistem Pemidanaan Terhadap Pelaku Tindak Pidana Penyalahguna Narkotika, Jurnal Daulat Hukum Vol. 1. No. 1 March 2018 ISSN: 2614-560X, Unissula

[3] Hera Saputra, Munsyarif Abdul Chalim, Penerapan Sistem Pemidanaan Terhadap Pelaku Tindak Pidana Penyalahgunaan Narkoba (Studi Kasus di Polda Jateng), Jurnal Daulat Hukum Vol. 1. No. 1 March 2018 ISSN: 2614-560X, Unissula 
[4] Sepha Dwi Hananto, Anis Mashdurohatun, Jawade Hafidz, Penegakan Hukum Pidana Terhadap Terdakwa Pengguna Narkoba Yang Menjalani Rehabilitasi Di Polda Jateng, Jurnal Hukum Khaira Ummah Vol. 13. No. 1 March 2018

\section{Books:}

[1] Bambang Hariyono. (2009). Kebijakan Formulasi Hukum Pidana Terhadap Pelaku Tindak Pidana Narkoba di Indonesia. Universitas Diponegoro Semarang

[2] Juliana Lisa, Nengah Sutrisna. (2003). Narkoba Psikotropika dan Gangguan Jiwa. Yogyakarta: Nuha Medika

[3] Kusno Adi. (2009). Kebijakan Kriminal Dalam Penanggulangan Tindak Pidana Narkotika Oleh Anak. Malang: UMM Press

[4] Lydia Harlina Martono \& Satya Joewana. (2006). Membantu Pemulihan Pecandu Narkoba dan Keluarganya. Jakarta: Balai Pustaka

[5] Muhammad Taufik Makarao. (2003). Tindak Pidana Narkotika. Jakarta: Ghalia Indonesia.

[6] Romli Atmasasmita. (1996). Sistem Peradilan Pidana Indonesia. Jakarta: Putra Bardin

[7] Ronny Hanitijo Soemitro. (1998). Metode Penelitian Hukum dan Jurimetri. Jakarta: Ghalia 